Gi rask respons på artikler gjennom artikkelens kommentarfelt på tidsskriftet.no. Respons som er postet innen én måned etter at artikkelen er publisert, vurderes for publisering som Brev til redaktøren i papirutgaven.

Redaksjonen forbeholder seg retten til å foreta redaksjonelle endringer.

Forfattere av vitenskapelige artikler har tilsvarsrett, jf. Vancouver-gruppens regler.

\section{Sentralisering av bekkenreservoarkirurgien}

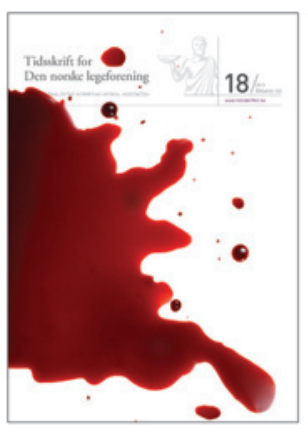

I Tidsskriftet nr. 18/2013 (1) påpeker Wasmuth \& Øresland betimelig at volumet av bekkenreservoarkirurgi i Norge er blitt betydelig redusert i løpet av det siste tiåret. Dette skyldes blant annet bedre medikamentell behandling og tettere koloskopisk oppfølging som giør at pasienter uten symptomer trygt kan avvente operasjon med proktokolektomi. Som ansvarlig for reservoarkirurgien for befolkningen i de tre nordligste fylkene er vi, på bakgrunn av denne nedgangen i antall inngrep, enige med forfatterne at reservoarkirurgien bør sentraliseres.

Et ytterligere poeng som også nevnes, er behovet for et team som kan ta seg av oppfølgingen av denne pasientgruppen. Selv om de fleste pasientene er godt fornøyd med funksjonen etter inngrepet, vil mange ha behov for undersøkelser og ulike behandlinger i årene etter at reservoaret er anlagt. Så det burde ikke være stor uenighet i fagmiljøet om at disse inngrepene burde være sentralisert. Så langt alt bra.

Men avslutningsvis kommer imidlertid den vanskelige øvelsen, der vi mener Wasmuth \& Øresland klart snubler på målstreken. Forfatterne mener at på grunnlag av årlig antall inngrep nasjonalt burde ikke mer enn to sentra uføre bekkenreservoarkirurgi i Norge. Dette er ikke basert på annet en personlig oppfatning av hvor mange inngrep et team må gjør årlig for å være kvalifisert. Grensen er absolutt ikke basert på faglige data.

Det er en rekke forhold som avgjør hvor kvalifisert en kirurg er i forhold til å anlegge bekkenreservoar. Årlig antall utførte inngrep er bare én av faktorene. Andre faktorer som også spiller inn, er hvor mange andre større kirurgiske inngrep i samme område kirurgen og teamet utfører. Lav fremre rektumreseksjon med anastomose på bekkenbunnen har mange fellestrekk med reservoarkirurgi, og en maskinsydd anastomose legges på samme vis. Om kirurgen i tillegg regelmessig opererer fistler med fullveggs forskyvningslapp av rektum ned til linea dentata, gir dette også ferdigheter som operatøren drar nytte av i de tilfeller der reservoaret må håndsys til anus. Bekkenreservoarkirurgien kan ikke ses helt løsrevet fra kirurgens og teamets øvrige proktologiske ekspertise.

Når Wasmuth \& Øresland mot slutten av sin kommentar bruker laparoskopisk kirurgi som ytterligere et argument for sentralisering, burde det nesten være etterfulgt av en oppfordring om henvise pasientene til gastrokirurgisk avdeling, Universitetssykehuset NordNorge. Så langt vi vet, er vi den eneste avdelingen i Norge som rutinemessig utfører dette inngrepet laparoskopisk.

Vi mener at det er viktig å styrke kompetansen omkring bekkenreservoarkirurgi, og vi synes den beste løsningen for det norske fagmiljøet vil være at hver helseregion har et fullverdig behandlingstilbud for denne pasientgruppen. På denne måten kan vi styrke kvaliteten på avansert proktologisk kirurgi i hele landet. Om forslaget til Wasmuth \& Øresland vinner frem, vil det føre til en generell utarming av det samme.

Stig Norderval

stig.norderval@unn.no

Rolv-Ole Lindsetmo
Stig Norderval (f. 1961) er overlege ved Gastrokirurgisk avdeling, Universitetssykehuset Nord-Norge, Tromsø. Han er også fag-og forskningsansvarlig ved Nasjonal tjeneste for inkontinens og bekkensykdom, samme sted, og førsteamanuensis II ved Institutt for klinisk medisin, Norges arktiske universitet - Universitetet i Troms $\emptyset$.

Ingen oppgitte interessekonflikter.

Rolv-Ole Lindsetmo (f. 1959) er avdelingsoverlege ved Gastrokirurgisk avdeling, Universitetssykehuset Nord-Norge, Troms $\varnothing$. Han er også professor II ved Institutt for klinisk medisin, Norges arktiske universitet Universitetet i Troms $\varnothing$.

Ingen oppgitte interessekonflikter.

\section{Litteratur}

1. Wasmuth HH, Øresland T. Bekkenreservoar - sporadisk kirurgi bør sentraliseres. Tidsskr Nor Legeforen 2013; 133: 1914.

Dette er en redigert versjon av debatten, publisert på nett 28.10.2013. http://tidsskriftet.no/article/3065463/

\section{Elektrokonvulsiv terapi ute av kontroll?}

Med bakgrunn i at Food and Drug Administration i USA har klassifisert elektrokonvulsiv terapi (ECT) som en høyrisikometode, maner psykolog Roar Fosse i Tidsskriftet nr. 18/2013 til forsiktighet ved bruk av elektrokonvulsiv terapi også i Norge (1).

Elektrokonvulsiv terapi er en akseptert behandlingsmetode for alvorlig depresjon der annen behandling ikke har ført frem. Det er imidlertid problematisk at virkningsmekanismen ikke kan forklares, og at bivirkningene, særlig hukommelsessvikten, kan være plagsom og langvarig.

Moksnes og medarbeidere (2) har kartlagt bruken ved Oslo universitetssykehus, Ullevål i perioden 1988-2002, og de fant betydelig økning. De viser også til studier som viste at diagnosen kun forklarte $10 \%$ av variasjonen i bruken. Psykiaterens kjønn, opplæring og kliniske orientering var viktigere. Innleggelsesrater, profesjonelle holdninger og pasientflyt predikerte mange av variasjonene sykehusene imellom (3-5).

I retningslinjer fra National Institute for Health and Clinical Excellence (NICE) (6) peker man på at det er sprikende opplysninger om alvorligheten av bivirkningene. I en britisk metaundersøkelse, med pasienterfaringer basert på 35 brukerundersøkelser (7), konkluderer man med: Omtrent en tredel av pasientene rapporterer om hukommelsesproblemer etter elektrokonvulsiv terapi. Rutinemessig nevropsykologisk testing fanger ikke opp den type hukommelsessvikt pasientene klager over, og brukertilfredshet med elektrokonvulsiv terapi avhenger betydelig av måten spørsmålene stilles på.

Det virker ikke som om noen er uenig i den formelt strenge indikasjonen for bruken, men er det praktiske bruksområdet likevel i ferd med å utvides? Jeg blir bekymret når jeg hører at pasienter med stemningssvingninger som ledd i personlighetsforstyrrelser får elektrokonvulsiv terapi, at man praktiserer vedlikeholdsbruk, at pasienter som selv ønsker elektrokonvulsiv terapi, får det, selv om indikasjonen mangler, og at det gis mot pasientens vilje på «vital indikasjon». 
Norsk pasientskadeerstatning (NPE) opplyser at fra 2003 og frem til i dag har de fattet i alt 54 vedtak som gjelder elektrosjokkbehandling: sju medhold og 47 avslag. Medholdssakene dreier seg mest om varig kognitiv skade, hukommelsesplager og blodpropp som følge av at det enten ble utført for mange behandlinger, eller at det ikke var indikasjon for behandlingen. Avslagene er begrunnet med at det ikke er noen sammenheng mellom behandlingen og skaden pasienten mener å ha fått, eller at pasientens plager er en kjent komplikasjon (seniorrådgiver Sølvi Flåte i Norsk pasientskadeerstatning, personlig meddelelse).

Etter min mening bør vi sette et skarpere søkelys på bruk av elektrokonvulsiv terapi i Norge. Man bør føre en samlet oversikt over indikasjon og bruk. Bivirkningene bør registreres systematisk, slik det skjer med medikamentell behandling. Man bør gjennomføre brukerundersøkelser og «benchmarking». Jeg stoler på at Helsedirektoratet greier å gjøre en god kunnskapsoppsummering, men utfordringen er å utvikle et helsepolitisk syn på bruken i Norge, slik man har gjort med bruk av tvang.

Ole Steen

oles@uus.no

Ole Steen (f. 1952) er avdelingsoverlege ved Klinikk psykisk helse og avhengighet, Oslo universitetssykehus.

Ingen oppgitte interessekonflikter.

\section{Litteratur}

1. Fosse R. Tvilsomme effekter av elektrokonvulsiv behandling. Tidsskr Nor Legeforen 2013; 133: 1915-6

2. Moksnes KM, Vatnaland T, Eri B et al. Elektrokonvulsiv terapi i Ullevål sektor i Oslo 1988-2002. Tidsskr Nor Legeforen 2006; 126: 1750-3.

3. Babigian HM, Guttmacher LB. Epidemiologic considerations in electroconvulsive therapy. Arch Gen Psychiatry 1984; 41: 246-53.

4. Hermann RC, Ettner SL, Dorwart RA et al. Characteristics of psychiatrists who perform ECT. Am J Psychiatry 1998; 155: 889-94.

5. Latey RH, Fahy TJ. Some influences on regional variation in frequency of prescription of electroconvulsive therapy. Br J Psychiatry 1988; 152: 196-200.

6. NICE. Guidance of the use of electroconvulsive therapy. http://publications. nice.org.uk/guidance-on-the-use-of-electroconvulsive-therapy-ta59 (4.11.2013).

7. Rose D, Fleischmann P, Wykes T et al. Patients' perspectives on electroconvulsive therapy: systematic review. BMJ 2003; 326: 1363

Dette er en redigert versjon av debatten, publisert på nett 19.10.2013. http://tidsskriftet.no/article/3065527/

\section{Tvilsom kritikk av elektrokonvulsiv behandling}

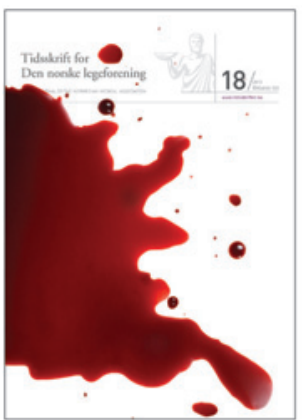

I Tidsskriftet nr. 18/2013 kommer Roar Fosse med en rekke påstander om elektrokonvulsiv behandling (ECT) (1). Jeg har gått grundig gjennom alle punktene og kan her bare berøre de viktigste.

Mer langsom aktivitet i hvile-EEG etter elektrokonvulsiv behandling betyr ikke svekkede hjernefunksjoner, som Fosse hevder. Ved depresjon er pasienten anspent og grublende med økt høyfrekvent EEG-aktivitet (2). Etter elektrokonvulsiv behandling avtar dette, og uspesifikk, langsom aktivitet øker på grunn av bedre evne til avkobling. Ved aktivering under registreringen forsvinner denne økningen (3).

Kortvarig, lett kortisolstigning etter den enkelte elektrokonvulsive behandlingen gir neppe «svekkelse», bl.a. fordi den normale støtvise kortisolutskillingen har langt høyere topper (4). Vedvarende hyperaktivitet i hypothalamus-hypofyse-binyrebark-aksen (HPA-aksen) ved depresjon normaliseres av effektiv elektrokon- vulsiv behandling. Kortikotrofinutløsende hormon reduseres. Økning av nevroner, endotelceller, dendritter og synapser i hippocampus etter elektrokonvulsiv behandling tyder på normalisering etter depresjon. Vedvarende aktivering av HPA-aksen svekker dette. Volumet av hippocampus er redusert ved depresjon, men øker etter elektrokonvulsiv behandling, motsatt som ved skade (5-7).

Fosse mener at to dyrestudier dokumenterer at elektrokonvulsiv behandling medfører «celledød» i gyrus dentatus (8). Ingen av disse studiene har relevans for klinisk elektrokonvulsiv terapi fordi det ble brukt skadelige stimuleringsmåter. Sju andre kvantitative studier på rotte viste intet nevrontap, og én viste økt antall kornceller og volum av hippocampus. I nye studier på rhesusaper med modifisert elektrokonvulsiv behandling, som hos mennesker, fant man ingen endring i volum eller celletall, men økning av prekursorcelleproliferasjon og et nevrobeskyttende genprodukt (9).

Autopsier har ikke vist celletap eller gliose, og computer- og magnettomografi har ikke vist endringer etter elektrokonvulsiv terapi. Magnetisk resonansspektroskopi har vist uendret celletall i hippocampus og normalisering av et for lavt signal for dendritter og synapser (10).

Relevante studier viser altså at elektrokonvulsiv behandling ikke gir hjerneskade, men endringer som motvirker depresjon $(5-7,9,10)$.

\section{Per Bergsholm}

per.bergsholm@gmail.com

Per Bergsholm (f. 1945) er overlege ved Klinikk psykisk helse og avhengighet, Oslo universitetssykehus.

Ingen oppgitte interessekonflikter.

Litteratur

1. Fosse R. Tvilsomme effekter av elektrokonvulsiv behandling. Tidsskr Nor Lege foren 2013: 133: 1915-6.

2. Jeong H-G, Ko Y-H, Han $\mathrm{C}$ et al. Distinguishing quantitative electroencephalogram findings between adjustment disorder and major depressive disorder Psychiatry Investig 2013; 10: 62-8.

3. Thimmaiah R, Thirthalli J, Ramesh VJ et al. Effect of a course of electroconvulsive therapy on interictal bispectral index values: a prospective study. J ECT 2012; $28: 20-3$

4. Sherman B, Pfohl B, Winokur G. Circadian analysis of plasma cortisol levels before and after dexamethasone administration in depressed patients. Arch Gen Psychiatry 1984: 41: 271-5.

5. Pittenger $C$, Duman RS. Stress, depression, and neuroplasticity: a convergence of mechanisms. Neuropsychopharmacology 2008; 33: 88-109.

6. Bolwig TG. How does electroconvulsive therapy work? Theories on its mechanism. Can J Psychiatry 2011; 56: 13-8.

7. Bolwig TG, Madsen TM. Electroconvulsive therapy in melancholia: the role of hippocampal neurogenesis. Acta Psychiatr Scand Suppl 2007; 115 (433): 130-5

8. Fosse R. Mer skade enn effekt. Tidsskrift for norsk psykologforening 2012; 49: $296-7$

9. Dwork AJ, Christensen JR, Larsen KB et al. Unaltered neuronal and glial counts in animal models of magnetic seizure therapy and electroconvulsive therapy. Neuroscience 2009; 164: 1557-64

10. Obergriesser T, Ende G, Braus DF et al. Long-term follow-up of magnetic resonance-detectable choline signal changes in the hippocampus of patients treated with electroconvulsive therapy. J Clin Psychiatry 2003; 64: 775-80.

Dette er en redigert versjon av debatten, publisert på nett 29.10.2013.

http://tidsskriftet.no/article/3065527/

\section{R. Fosse svarer:}

En av Bergsholms kommentarer på min artikkel om effekter av elektrokonvulsiv behandling er at redusert aktivitet i frontotemporale nettverk ikke avspeiler en funksjonssvikt, men heller at pasientene har fått en «bedre evne til avkobling». Evidensen om at elektrokonvulsiv behandling svekker frontotemporal aktivitet er det mest sentrale i min kritikk, og jeg kommenterer her kort på dette. En mer omfattende kommentar finnes på Tidsskriftets nettside.

Alvorlig/psykotisk depresjon er karakterisert ved redusert aktivitet $\mathrm{i}$ frontotemporale nettverk, særlig i dorsolateral prefrontal 